\title{
The Community Health Clinics as a learning context for student nurses
}

\author{
MB Makupu \\ M.Cur \\ Masterstudent \\ Rand Afrikaans University
}

\&

A Botes
D.Cur

Department of Nursing Science Rand Afrikaans University
"In a changing pattern of health care delivery towards

comprehensive health

services, community

health clinics are

expected to provide a

primary health care

service according to

the National Health

plan, to meet the

needs of the country."

\section{Abstract}

The purpose of the research study was to describe guidelines to improve the community health clinics as a learning context conducive to learning. The objectives of the study commenced by getting the perception of student nurses from a nursing college in Gauteng; community sisters from ten community health clinics in the Southern Metropolitan Local Council and college tutors from a college in Gauteng. The research design and method used, consisting of a qualitative, exploratory, descriptive and contextual approach and the design was divided into two phases. Phase one consisted of a field/empirical study and phase two of conceptualization. In all the samples follow-up focus group interviews were conducted to confirm the findings. To ensure trustworthiness, Lincoln and Guba's model (1985) was implemented and data analysis was according to Tesch's model (1990 in Creswell 1994:155) based on a qualitative approach. The conceptual framework discussed, indicating a body of knowledge, was based on the study and empirical findings from phase one to give clear meaning and understanding regarding the research study.

The research findings were then compared with existing literature within the framework, to determine similarities and differences as literature control method. Guidelines were then formulated from phase one and two to solve the indicated problems based on the three different sample groups. Ethical consideration was maintained throughout the research study. Recommendations related to nursing education, nursing practice and nursing research were indicated accordingly.

\section{Opsomming}

Die doel van die navorsing is om riglyne daar te stel vir die bevordering van gemeenskapsgesondheidsklinieke as 'n leer-konteks bevorderlik vir leer. Die navorsingsdoelwitte het ' $n$ aanvang geneem deur die beskouing van studente verpleegkundiges van ' $n$ verpleegkollege in Gauteng; verpleegkundiges van tien gemeenskapsgesondheidsklinieke in die Suidelike Metropolitaanse Plaaslike Raad en dosente van ' $n$ kollege in Gauteng te verkry. Die toegepaste navorsingsontwerp en -metode het bestaan uit ' $n$ kwalitatiewe, verkennende, beskrywende en kontekstuele benadering en die ontwerp is in twee fases verdeel. Die eerste fase het ' $n$ veld/empiriese studie behels en die tweede fase het bestaan uit konseptualisering. In al die steekproewe is opvolg fokusgroep onderhoude gevoer ter bevestiging van die bevindinge. Om vertrouenswaardigheid te verseker, is Lincoln en Guba (1985) se model geimplementeer en data-analise is gedoen op grond van Tesch (1990 in Creswell (1994:155) ) se model, gebaseer op ' $n$ kwalitatiewe benadering. Die bespreekte konseptuele raamwerk, wat ' $n$ kennisraamwerk aandui, is gebaseer op die studie en empiriese bevindinge van fase een om sodoende duidelike betekenis en begrip van die navorsing te verseker.

Die navorsingsbevindinge is daarna vergelyk met bestaande literatuur binne die raamwerk, om die ooreenkomste en verskille as literatuurkontrole-metode te bepaal. Riglyne is geformuleer vanuit beide fases om die aangeduide probleme, gebaseer op die drie verskillende steekproefgroepe, op te los. Etiese konsiderasie is deurgaans toegepas. Aanbevelings ten opsigte van verpleegkundige opleiding, verpleegkunde en verpleegkundige navorsing is gemaak. 


\section{Introduction and}

\section{problem statement}

The research study focused on a learning context for student nurses within the community health clinics not conducive to learning, preventing student nurses from becoming sufficiently competent. The intention of this article is to describe the two phases of the research, where phase one consisted of a field (empirical) study and phase two consisted of conceptualization with the purpose of describing guidelines to improve the community health clinics as a learning context, in order to be conducive for learning

In a changing pattern of health care delivery towards comprehensive health services, community health clinics are expected to provide a primary health care service according to the National Health plan, to meet the needs of the country. The South African Nursing Council, as a regulatory body for Nursing Education, expects community health clinics to create a learning context conducive to learning, as an educational requirement for the education and training of a nurse (general, psychiatric and community) and midwife, leading to registration (according to regulation R425 of 22 February 1985). Student nurses should be assisted by community sisters to render a promotion and preventative service, as expected by their teaching programme, to do their clinical practicals in order to correlate theory and practice

It appears as if the learning context for student nurses within the community health clinics is not conducive to learning, preventing student nurses from becoming sufficiently competent. Troskie (1993:5) describes the competency of the student nurses having completed the course, as being queried by senior members of the profession. Students lack technical skills as a result of lacking experience. They also have insufficient leadership skills. As a result, the desired learning outcome within the learning context becomes affected.

\section{Purpose and \\ objectives of the}

\section{research study}

The purpose of the research is to describe guidelines to improve the community health clinics as a learning context, in order to be conducive for learning. To realize the purpose of the research, the following research objectives are stated:

- To explore and describe the problems experienced by student nurses, in relation to community health clinics as a learning context. (Step 1 of phase 1).

- To explore and describe the problems experienced by community sisters in relation to community health clinics as a learning context. (Step 2 of phase 1).

- To explore and describe the problems experienced by community health science tutors in relation to community health clinics as a learning context. (Step 3 of phase 1)

\section{Definition of central concepts}

The following definitions will apply to the research:

Student nurse: A student nurse is a fourth year student in a programme leading to registration as a nurse (general, psychiatric and community) and midwife at a specific nursing college in Gauteng (SANC, Reg. 425 of 1985, as amended).

Community sister: A community sister can work in any setting within the Southern Metropolitian Local Council community health clinics whereby the know! edge of community health nursing science makes her a community sister who is registered with the South African Nursing Council (Dreyer et. al., 1994:4).

Community clinical context as learning context: Describes community health clinics as a learning context allowing student nurses to gain skills, values and knowledge while also making them feel accepted, despite difference of opinion and perspective.

Learning outcome: The desired endresults are called the learning outcome and student nurses need to demonstrate that they have attained values, knowledge and skills to function as independent practitioners within the legal and ethical framework of nursing, and be a member of the health team in the promotion and prevention of health to the individual, family and community.

\section{Research design and methods}

The research study used a qualitative, exploratory, descriptive and contextual design (Creswell, 1994: 145) to achieve the intended goal.

The design was divided into two phases: Phase one consisted of a field (empirical) study and phase two of conceptualization. Phase one consisted of three steps, as indicated with objectives of the study.

\section{Phase I}

\section{Step 1: Student nurses' view}

Population included all the fourth year students $(N=108)$ from a specific nursing college in Gauteng who were in an education programme leading to registration as a nurse (general, psychiatric and community) and midwife according to SANC (Reg. 425, 1985 as amended).

For student nurses to participate they should have completed their third year theory and practicals, including their clinical evaluation assessment. They were a mixed group of males and females $(N=108)$. Participants were selected by means of systematic random sampling (De Vos, 1998:193) from the student class list. Sample of ten students $(n=10)$ were selected for the focus group interviews (Krueger, 1994). Follow up focus group interviews were conducted to confirm the findings with a sample size eight $(n=8)$.

\section{Step 2 Community sisters' view:}

Community sisters from the Southern Metropolitan Local Council were the second group to participate in the empirical phase of this research. They were all registered with the SANC (Diploma in Community Nursing Science).

Participants were selected for the focus group interview (Krueger, 1994) by means of purposive sampling (De Vos, 1998:198). Ten $(n=10)$ subjects, one from each of ten community health clinics, were included in the sample. Followup focus group interviews were conducted to confirm the findings.

\section{Step 3 Community science tutors}

Population consisted of community nursing science tutors of a particular college in Gauteng, who were all registered with the South African Nursing Council as tutors and had more than two years experience in the college. The interviews took place during a transformation period where colleges were integrated with other nursing colleges in Gauteng. The total population of community nursing science tutors $(\mathrm{N}=7)$ participated in the focus group interviews (Krueger, 1994) Follow-up focus group interviews were conducted with the same group.

Data collection was conducted by means of focus group interviews (Krueger 1994) in Steps I, II and III, involving a number of participants with common experiences of characteristics for the purpose of eliciting ideas, thoughts and perceptions about the 
phenomenon to be studied. The following questions were asked:

- What learning /teaching problems have you experience in community health clinics as a learning context for student nurses?

- How can we assist you/student nurses to achieve their learning outcomes in the community health clinics as learning context?

A tape recorder and field notes were used as tools to help capture everyone's comments. Data analysis was conducted based on certain principles, methods and strategies. The work of Tesch (1990 in Creswell, 1994:154) provided eight steps to be considered in data analysis. The primary purpose of qualitative analysis being to discover and reveal the perspective of people and the meanings assigned to their experiences interpreting the world as it appears.

\section{Phase II}

Phase two consisted of conceptualisation. Mouton (1996:109) describes conceptualization as the clarification and analysis of the key concepts in a study and also to the way in which one's research is integrated into the body of existing theory and research. The primary purpose for reviewing relevant literature was to gain a broad background to understand the information available, relating to the phenomenon The comparison between the empirical findings and existing literature gave clear meaning and understanding of the phenomenon under study.

Guidelines were formulated from phase 1 and 2 as solutions to the identified

\section{Table 1 Measures for trustworthiness}

\begin{tabular}{|l|l|}
\hline CRITERION AREA & MEASUREMENTS \\
\hline Credibility & $\begin{array}{l}\text { 1. Activities that increase the probability of high } \\
\text { credibility }\end{array}$ \\
& $\begin{array}{l}\text { - Prolonged engagement } \\
\text { 2. Peer debriefing: Colleagues and researchers }\end{array}$ \\
Transferability & $\begin{array}{l}\text { 3. Member checking: Experts and during follow } \\
\text { up interview. Participants from all samples. }\end{array}$ \\
4. Thick description: Research methodology fully \\
Confirmability \\
Reflexibility
\end{tabular}

sult in a lack of accompaniment of the students doing their practica, resulting in poor supervision.

3. The lack of communication and coordination between the college authority, students and the community sisters result in poor relationships, making it difficult for the students to interact effectively within the community health clinics.

4. A poor teaching approach at the community health clinics discourages student nurses towards effective learning and they sometimes become confused and demotivated to learn, in order to achieve their learning outcome.

5. Some of the community sisters are demotivated and not committed to teaching, thus resulting in student nurses finding it difficult to holistically adjust to the community health clinics as a learning context.

6. Some sisters have a negative attitude towards teaching the students, thus resulting in a lack of respect for the students and subsequently resulting in students having a lack of interest in the community health clinics.

7. The lack of necessary equipment / resources in the community health clinics makes it difficult for student nurses to be competent and also to be confident.

\section{Unique problem from the empirical phase identified in step III}

8. The teaching programme at the college does not encourage student nurses to participate actively at the community health clinics.

\section{Conceptual framework (phase 2)}

The conceptual framework for the study is reflected in figure 1. Figure 1 will be used to guide the discussion of the conceptual framework for the research.

\section{National health plan}

The National Health Plan for South Africa discussed in relation to the $\mathrm{PHC}$ approach involving complete transformation of the entire delivery system. The National Health Plan is based on the reconstruction and development programme of the government and focuses on the provision of PHC services as a 
priority, within the community health clinics at local government levels. "It embodies the concept of community development, and is based on full community participation in the planning, provision, control and monitoring of services" (African National Congress, 1994:19).

The African National Congress (1994:45) further states that statutory bodies should be able to promote and protect the rights and interest of patients and also of the clients. This will lead to improved physical, mental and social health for the entire population to facilitate a shift from disease or illness, to health.

\section{South African nursing council philosophy and \\ nursing education}

The objectives of the South African Nursing Council, as a controlling regulatory body, are determined in section three of the Nursing Act, 1978 (No 50 of 1978). The primary aim being to set standards, promote and control standards of such education and training, and the manner of the exercise of such practices in the Republic (South African Nursing Council Philosophy, 1992:1). The use of standards in community teaching ensures that student nurses become experts in their clinical learning context.
The didactic and subject competence of the tutor, academically and clinically is essential.

\section{Community clinical learning context and resources}

For any given clinical learning context with its own norms, values and group phenomena, students undergo influences through the process of professional socialization to functional independent members (Oermann, 1991:13). Students should also be allowed to explore the learning context freely to understand certain events within the com-

\section{Figure 1 : Conceptual framework for the study}

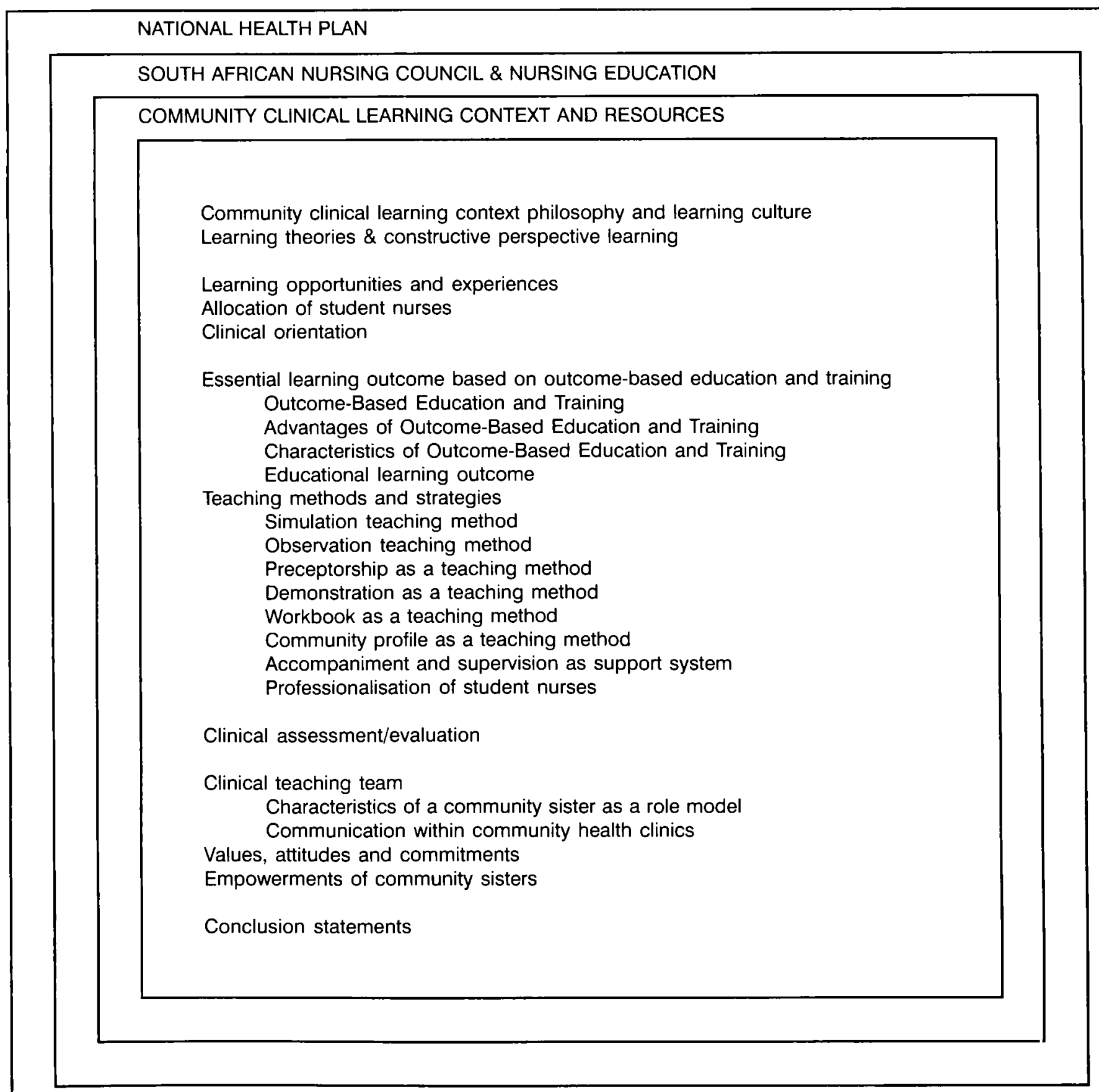


munity context (Mathews \& Whelan, 1993:226).

"Teaching is an interactive process which requires involvement of the teacher and learner in a supportive and facilitative learning environment" (Reilly and Oermann, 1992:109). Quinn, 1988:397, further states that in a supportive learning context, the teacher should accept differences among students, also in the way they analyze certain situations. White and Ewan 1994:5, emphasize that they should always be encouraged to have a deep urge to learn in a nonthreatening manner.

\section{The community clinical learning context philosophy and learning culture}

A philosophy can be described as a statement of beliefs that reflects our values and orientation to life which forms the basis for our practice and professional activities Dreyer et al (1990:5). The philosophy of community health nurses thus forms an integral part of community health nursing science. Airhihenbuwa (1995:6) emphasises that in health promotion and behavioural change programmes, should be consistent with community's cultural framework.

\section{Learning theories and constructivistic \\ perspective of learning}

A number of influential learning theories discussed, describe how students can learn better in a community learning context, so that the principle of meaningful learning can be applied at all levels of student nurses. Qwinn (1995:2) emphasizes the most important qualities required for a facilitator whilst considering a student-centred approach. "The end result of this learner-centred approach was the view that adult learners should come to control their own education" Rodgers (1992:37). Klopper (1994:20) placed emphasis on the constructivistic perspective of learning and that conceptual change always take place. Knowles (1980:25) also emphasizes that a wide variety of institutions accomplish specific educational objectives.

\section{Learning opportunities and experiences}

Opportunities should be written in easily understood terminology and must be realistic and attainable (Matthews \& Whelan, 1993:228). Van Der Horst and Mc Donald (1997:226) state that learning can also occur in terms of consider- ing other circumstances to which the outcome might apply, deducing rules and principles from experiences.

\section{Allocation of student \\ nurses}

The increased numbers of students and the lengthier time that they are out on community placements also poses issues for accountability (Watson, 1995:136). Allocation should also allow student nurses to explore the learning context to gain good practice without any disturbance (Hinchliff 1979:42).

\section{Clinical orientation}

O'Conner (1986:398) describes orientation as the process by which new staff are introduced to the philosophy, goals, policies, procedures, role expectations, physical facilities and special services in a specific work setting.

\section{Essential learning outcome based on outcome based education and training}

Van der Horst and McDonald (1997:4) cited that outcomes are the results of learning processes and refer to knowledge, skills, attitudes and values. Learners' performance should be described in terms of observable, demonstrable and assessable manners, containing action verbs, which have clear meaning, containing reference to knowledge, skills, habits of mind, attitudes and values.

\section{Teaching programme based on outcome based education and training}

Bengu (1997:1) describes teaching approach as aiming at equipping all learners with the knowledge, competence, skills, and orientation about the learning context, to be successful once they complete their training. Ruth (1979:14) further describes the purpose of the curriculum model as teaching approach to ensure those goals that are congruent with the needs of the learner and society. The teaching programme forms patterns of instructions that cut across all dimensions of the learning context and provide continuous, sequential, integrated cumulative learning. Boschee \& Baron (1993:2) emphasise that all student nurses should be granted opportunities to reach their full potential.

\section{Teaching methods and strategies}

Should be used to link theory to practice, allowing students to understand the clinical learning context better. MortonCooper \& Palmer (1993:120) emphasize that nothing can be taken for granted when it comes to learning and preceptorship actually set the tone for future professional relationships. Mellish (1992:152) emphasizes that work books can be used while undertaking community health practica. SANC (1992:8) emphasise accompaniment and supervision of the student nurses. Cohen (1981:20) emphasises that the internalization of the professional role causes stabilization of the self concept.

\section{Clinical assessment/ evaluation}

Assessment should be done throughout the learning process as an integral part of all planning and preparation. Schalock (1995:6) requires outcome based evaluation to be based on performance assessment which is a concept that has captivated the attention of policy practitioners and programme evaluators. Continuous assessment offers a much more valid and reliable sample of behaviour, as well as making the assessment more realistic. Summative assessment is usually conducted at the end of a course.

\section{Clinical teaching team}

The key to successful team teaching lies in two areas: the interpersonal relationships of the team members and the quality of the planning. A team manager should ensure that each member carries an equal weight of work and meets educational responsibilities.

"As a healthcare professional, it is crucial for you to be engaged in active, positive programming of your own life in order to be good physical and emotional role models for your patients and fellow professionals" (Strassen, 1992:42). Ellis and Heartley (1995:22) emphasise appropriate feedback and re-enforcement. O'Brian (1978:3) further emphasizes the ability to influence another person through communications should never be underestimated.

\section{Values attitudes and commitments}

Tadd (1998:8) describes values as a particular type of belief, concerned with the worth of an idea or type of behaviour. Tschudin (1994:85) also emphasizes a very consistent and comprehensive set of values of caring preceptors/mentors should consider is: compassion, competence, confidence, conscience and commitment. Steele and Harmon (1979:9) describe value clarification as bringing personal growth and establishing values that are consistent and help in the deci- 
sion-making process.

\section{Empowerment of \\ community sisters}

Foder and Dalis (1989:160) state that inservice education is the primary purpose to improve teacher competencies in teaching and improving the standards of the professions in general, mainly by exchanging ideas with resource persons and colleagues. Opportunities should always be provided, based on the policy, to ensure that all preceptors/mentors are always kept up to date.

\section{Guidelines}

The following guidelines are the possible solutions for the identified problems within the community health clinics as learning context for student nurses:

\section{Guideline 1}

The allocation of student nurses to community health clinics should be planned by the college authority and co-ordinated with the community health services.

Student nurses should be under supervision of preceptors, to ensure proper guidance to one group at a time highlighting learning outcome to be achieved. A learning contract should be established to give the student nurses a degree of control.

\section{Guideline 2}

An orientation programme for each community health clinic should be available, implemented and evaluated for each new group of student nurses.

The programme should be based on a cognitive, psychomotor and affective domain considering the primary health care approach. The use of preceptors should be emphasised as a support system, the use of equipment, allowing them to explore all the learning areas freely and utilizing all the learning opportunities.

\section{Guideline 3}

The teaching programme for each community health clinic should be based on specific course outcomes, leading to registration as a general nurse and midwife in co-ordination with the nursing college.

Educational learning outcome should be clear, simple and attainable, encouraging student nurses to achieve the necessary knowledge, skills and attitude based on a problem-centered approach. Continuous assessment to be done to rectify student mistakes until they be- come competent and confident about themselves.

\section{Guideline 4}

The teaching strategies in the community health clinics should be based on adult learning principles.

Student nurses should be treated as adults, who are motivated and ready to carry out their learning activities. The formulated outcomes should be used to structure the learning of the student nurses within the community health clinics. Positive interaction between the preceptors and the student nurses should be created, ensuring a positive learning climate.

\section{Guideline 5}

The teaching strategies should be problem-based to deep, holistic, life long and meaningful learning.

Preceptor should encourage students towards intentional learning, with the aim of in depth searching for underlying accusations of the context. They should actively participate in the learning process, be committed to remain pro-active in learning at all times in order to produce the desired outcome. The use of adult learning and constructivistic principles should be encouraged, including problem-based learning. They should be allowed to enter into constructive dialogue, to assist them in clinical judgement.

\section{Guideline 6}

The culture (values) in the community health clinics should be condusive to learning.

The culture of learning should be established utilizing good management, discipline and effective learning climate, as well as applying rules and providing assistance with the internalization of certain values.

Interpersonal relationships and communication patterns should be improved and threatening issues should be avoided. The level of support and trust should be increased to allow self control and personal enthusiasm.

\section{Guideline 7}

Preceptors/mentors should be appointed and trained for accompaniment of student nurses in the community health clinics to assist community sisters in their educational responsibility.

Preceptors should be appointed by means of a written agreement by the nursing education manager registered and experienced in accordance with the academic professional requirements of the teaching programme.

They should demonstrate knowledge of the student nurses programme based on regulation R425 of the SANC. They should be empowered regularly to remain knowledgeable and resourceful

\section{Guideline 8}

The competence of student nurses should be assessed/evaluated in coordination with the college authority.

Preceptors should have a protocol related to performance assessment, jointly formulated by the college authority and the community health clinical team to shape student nurses learning process. Assessment procedures should be clear, realistic, based on Outcome Based Education, considering adult learning principles. Transparency to be encouraged to increase trustworthiness and reliability.

\section{Guideline 9}

The community sisters in the community health clinics should be empowered for their roles as preceptors and facilitators of learning.

Empowerment sessions should be organised according to their needs and current changes, based on legislation to make them feel confident about themselves. The timetable for the sessions should be clear, realistic, and always available to the teaching team. There should be a policy pertaining to empowerment of all preceptors to encourage a learning culture for student nurses.

\section{Recommendations}

Recommendations are made based on the research findings and their applicability to nursing education, nursing research and nursing practice.

\section{Nursing education and nursing practice}

- Preceptors should have regular meetings with the college tutors to look into student nurses' problems, to enable them to reach their learning outcome. The culture in the community health clinics should remain conducive to learning for student nurses.

- A friendly, comfortable, disciplined atmosphere within the learning context should be created to allow student nurses a feeling of security and freedom to explore the clinical learning context.

- Management should be effective, avoiding threatening issues, applying rules and ensuring safe practice. 
- A teaching programme should be established and implemented based on student nurses' learning outcome, their levels, outcome based education and focusing on student centered approach, by using problem-based learning.

- Teaching should be based on adult learning principles and various guidelines. Effective orientation programme and briefing sessions should be conducted by the teaching team at a central point, emphasizing accompaniment use of preceptors, continuous assessment, use of equipment, teaching strategies, use of allocation and maintaining positive attitude. The student coordinator must liaise with the nursing education manager, the teaching team and the college authority regarding any issues related to the student nurses in terms of policies or changes, to ensure that there is effective communications and to strengthen the relationship.

\section{Nursing research}

Nursing research as a scientific process refines existing knowledge and generate new knowledge directly and indirectly. Further research may be necessary in the following ways:

- The teaching team within the community health clinics should focus on a team building approach.

- A comparison of colleges that teach student nurses leading to registration within Gauteng, related to the planning of students' practicals for community health clinics, should be considered.

- A quality assurance programme should include a values system and standards to evaluate the quality of teaching, based on set guidelines and positive, negative issues, related to teaching. Teaching should be directed towards excellence. 
AFRICAN NATIONAL CONGRESS, 1994. A national health plan for South Africa. Maseru, Lesotho.

AFRICAN NATIONAL CONGRESS, 1994. The reconstruction and development programme: A policy framework. Johannesburg.

AIRHIHENBUWA, OC 1995. Health and culture: Beyond the Western Paradigm. London: New Delhi.

BENGU, S 1997. Curriculum 2005. Lifelong learning for the $21^{\text {st }}$ century. Pretoria.

BOSCHEE, F AND BARON, MA 1993. Outcome Based Education. Developing programmes through strategic planning. USA.

COHEN, AH 198. The nurses' quest for a personal identity. London; Amsterdam.

CRESSWELL, S 1994. Research design: Qualitative and quantitative approach. London: Sage.

DE VOS, AS 1998. Research at grass roots. A primer for the caring professions. Pretoria: Van Schaik.

DREYER, M; HATTINGH, S \& LOCK, $M$ 1990. Fundamental aspects in community health nursing.

DENOSA 1997. Ethical standards for nurse researchers. Pretoria.

ELLIS, JR \& HARTLEY, CL 1995. Nursing in today's world. Challenges, issues and trends. $5^{\text {th }}$ edition. Philadelphia.

FODOR, JT \& DALIS, GT 1989. Health instruction. Theory and application. $4^{\text {th }}$ edition. United States of America.

HINCHLIFF, MS 1979. Teaching clinical nursing. London.

KLOPPER, HC 1994. A constructivistic perspective in learning. Nursing Science, Monograph III, RAU; Johannesburg.

KNOWLES, MS 1980. The modern practice of adult education. From pedagogy to andragogy. New York.

KRUEGER, RA 1994. Focus Groups. Second edition. London: Sage.

LINCOLN, YS \& GUBA, GE 1985. Naturalistic inquiry. London: Sage Publications.
MATHEWS, A \& WHELAN, J 1993.

Teaching in the ward. (Anon.)

MELLISH, JM 1982. Teaching the practice of nursing. London.

MORTON-COOPER A \& PALMER A, 1993. Mentoring and preceptorship. A guide to support roles in clinical practice. Canada.

MOUTON, J 1996. Understanding social research. Pretoria.

O'BRIEN, JM 1978. Communications and relationships in nursing. $2^{\text {nd }}$ edition. Saint Louis.

O'CONNOR, AM 1986. Nursing staff development and continuing education Toronto

QUINN, MF 1995. The principles and practice of nurse education. $3^{\text {rd }}$ edition. London.

REILLY, E \& OERMANN, MH 1992. Clinical teaching in nursing education. $2^{\text {nd }}$ edition. New York.

RODGERS, A 1992. Adults learning for development. New York, London.

RUTH, RW 1979. Designing a curriculum model. Journal of Nursing Education, Vol. 18(3), 1979:13-21.

SCHALOCK, RL 1995. Outcome Based Evaluation. New York, London.

SOUTH AFRICAN NURSING COUNCIL, 1985. Relation to the approval of and the minimum requirements for the education and training of a nurse (general, psychiatric and community) and midwife leading to registration. Regulation R425 (as amended). Nursing Act 1978.

SOUTH AFRICAN NURSING COUNCIL PHILOSOPHY, 1992. The philosophy and policy of the South African Council with regard to professional nursing education. Pretoria.

STEELE, MS \& HARMON, VM 1979. Values clarification in nursing. New York.

STRASSEN, L 1992. The image of professional nursing. Strategies for action. Philadelphia.

TROSKIE, 4 1993. Critical evaluation of the newly qualified nurse's competency to practice. Part 1. Curationis, Vol. $16(3), 1993: 50-55$
VAN DER HORST, S \& MCDONALD, R 1997. Outcome Based Education. A teacher's manual. Kagiso, Pretoria.

WHITE, R \& EWAN, C 1994. Clinical teaching in nursing. Tokyo. 